\title{
The effect of magnetite nanoparticles synthesis conditions on their ability to separate heavy metal ions
}

\author{
Magdalena Bobik ${ }^{1 *}$, Irena Korus ${ }^{1}$, Lidia Dudek² \\ ${ }^{1}$ Silesian University of Technology, Poland \\ Institute of Water and Wastewater Engineering \\ ${ }^{2}$ National Research Institute, Poland \\ Oil and Gas Institute
}

*Corresponding author's e-mail: magdalena.bobik@polsl.pl

Keywords: iron oxide nanoparticles, co-precipitation, heavy metals separation, adsorption.

\begin{abstract}
Magnetite nanoparticles have become a promising material for scientific research. Among numerous technologies of their synthesis, co-precipitation seems to be the most convenient, less time-consuming and cheap method which produces fine and pure iron oxide particles applicable to environmental issues. The aim of the work was to investigate how the co-precipitation synthesis parameters, such as temperature and base volume, influence the magnetite nanoparticles ability to separate heavy metal ions. The synthesis were conducted at nine combinations of different ammonia volumes $-8 \mathrm{~cm}^{3}, 10 \mathrm{~cm}^{3}, 15 \mathrm{~cm}^{3}$ and temperatures $-30^{\circ} \mathrm{C}, 60^{\circ} \mathrm{C}, 90^{\circ} \mathrm{C}$ for each ammonia volume. Iron oxides synthesized at each combination were examined as an adsorbent of seven heavy metals: $\mathrm{Cr}(\mathrm{VI}), \mathrm{Pb}(\mathrm{II}), \mathrm{Cr}(\mathrm{III}), \mathrm{Cu}(\mathrm{II}), \mathrm{Zn}(\mathrm{II}), \mathrm{Ni}(\mathrm{II})$ and $\mathrm{Cd}(\mathrm{II})$. The representative sample of magnetite was characterized using XRD, SEM and BET methods. It was observed that more effective sorbent for majority of ions was produced at $30^{\circ} \mathrm{C}$ using $10 \mathrm{~cm}^{3}$ of ammonia. The characterization of the sample produced at these reaction conditions indicate that pure magnetite with an average crystallite size of $23.2 \mathrm{~nm}$ was obtained (XRD), the nanosized crystallites in the sample were agglomerated (SEM) and the specific surface area of the aggregates was estimated to be $55.64 \mathrm{~m}^{2} \cdot \mathrm{g}^{-1}$ (BET). The general conclusion of the work is the evidence that magnetite nanoparticles have the ability to adsorb heavy metal ions from the aqueous solutions. The effectiveness of the process depends on many factors such as kind of heavy metal ion or the synthesis parameters of the sorbent.
\end{abstract}

\section{Introduction}

In recent years, nanomaterials have become an interesting and promising research object for many scientists due to their unique properties and applicability in various fields.

Among extensively studied nanomaterials, iron oxide nanoparticles can be distinguished. In the natural environment, iron oxides are available in many different forms. The most common ones include hematite $\alpha-\mathrm{Fe}_{2} \mathrm{O}_{3}$ maghemite $\gamma-\mathrm{Fe}_{2} \mathrm{O}_{3}$ and magnetite $\mathrm{Fe}_{3} \mathrm{O}_{4}$ (Teja et al. 2009). Synthesis of iron oxide nanoparticles are currently widely studied not only because of purely academic interest in their properties but also because of their practical application possibilities (Dave et al. 2014). Many works and articles describe various methods of the synthesis, modifications as well as physical and chemical properties characterization of magnetite and maghemite nanoparticles (Salado et al. 2008, Urquijo et al. 2011, Petcharoen et al. 2012, Mascol et al. 2013). The aim of studies is usually to obtain nanoparticles with the most suitable characteristics for the particular application field. Advances in the researches of nanomaterial usage in various fields proved among others the possibility of their application to environmental issues. A lot of attention is mainly focused on the synthesis and surface functionalization of nanoparticles with sizes below $50 \mathrm{~nm}$ which have a very large potential as adsorbents of contaminants such as heavy metals or organic compounds (Matei et al. 2011).

Heavy metals present in the aquatic environment pose a significant threat to human health. Many techniques are used to remove them from wastewater. Among them adsorption on iron oxide nanoparticles seems to be very attractive. Nanoparticles, as adsorbents, have many specific and useful features, such as small size, magnetic properties or high surface area (Dave et al. 2014). The adsorption mechanism between iron oxides and heavy metal ions is quite simple. In the water the iron oxides are completely hydrated. Their surface is covered by $-\mathrm{OH}$ functional groups which can react with $\mathrm{H}^{+}$and $\mathrm{OH}^{-}$ions. Depending on the $\mathrm{pH}$, the oxide surface can undergo pronation and behave as an acid or deprotonation - obtaining the base characteristics. The protonation/deprotonation reactions are presented below:

$$
\begin{gathered}
\mathrm{Fe}-\mathrm{OH}+\mathrm{H}^{+} \leftrightarrow \mathrm{Fe}-\mathrm{OH}_{2}^{+} \\
\mathrm{Fe}-\mathrm{OH}+\mathrm{OH}^{-} \leftrightarrow \mathrm{Fe}-\mathrm{O}^{-}+\mathrm{H}_{2} \mathrm{O} \text { or } \\
\mathrm{Fe}-\mathrm{OH} \leftrightarrow \mathrm{Fe}-\mathrm{O}^{-}+\mathrm{H}^{+}
\end{gathered}
$$


As a result, the above reactions can lead to the electrostatic attraction between heavy metal ions and the iron oxide surface. The important characteristic for considered adsorbent is $\mathrm{pH}$ of point of zero charge (pzc). The value point of zero charge $\mathrm{pH}$, depending on the literature source, can be placed somewhere between $6-6.8$. When $\mathrm{pH}$ is above this value the surface of magnetite is negatively charged and more likely to attract cations, in turn, below this value, the surface of the adsorbent is positively charged and more likely to adsorb anions (Dąbkowska-Naskręt 2009, Horst et al. 2015, Illés et al. 2006, Liu et al. 2008)

There are various iron oxide nanoparticles synthesis technologies. They can be divided into two main streams or experimental approaches: "top-down" and "bottom-up". The "top-down" approach, currently rarely used, is based on crushing or grinding of the material in ball mills. The "bottom-up" is more prevalent than the "top-down" approach mainly due to easier, less time-consuming, cheaper and more efficient synthesis of nanoparticles which, as a result, have better quality and smaller size distribution. There are a variety of "bottom-up" methods. They are mainly based on the chemical synthesis of nanomaterials, however, some physical processes are also in use. Thus, one can point out such "bottom-up" techniques as chemical precipitation, pyrolysis, sol-gel method, thermolysis of precursors or hydrothermal reactions etc. (Khan et al. 2011, Runowski et al. 2014).

One of the most popular is the method of magnetite nanoparticles synthesis by their chemical co-precipitation from a mixture of iron(II) and (III) salts by addition of a base in the form of aqueous ammonia and sodium or potassium hydroxide (Maity et al. 2006, Mascolo et al. 2013). In the literature, one can also find precipitation methods with only $\mathrm{Fe}(\mathrm{II})$ or $\mathrm{Fe}$ (III) salt solutions instead of their mixtures. For example, if the precipitation of iron oxides involves the use of $\mathrm{Fe}(\mathrm{II})$ salts only, the partial oxidation of $\mathrm{Fe}(\mathrm{II})$ to $\mathrm{Fe}(\mathrm{III})$ may be conducted by $\mathrm{H}_{2} \mathrm{O}_{2}$ addition - oxidative co-precipitation ( $\mathrm{Hu}$ et al. 2010). In the case of $\mathrm{Fe}$ (III) salts, the reduction of Fe(III) to $\mathrm{Fe}$ (II) can be initiated by $\mathrm{Na}_{2} \mathrm{SO}_{3}$ - reduction co-precipitation (Qu et al. 1999).

The popularity of chemical precipitation can be explained primarily by its simplicity, efficiency and low costs or productivity. This method enables the production of small, stoichiometric nanoparticles of high purity. Furthermore, the ability to control the synthesis conditions, such as $\mathrm{pH}$ of the reaction solution, the reaction temperature, speed of base addition, the concentration of solutes and the ionic strength of the reaction solution makes it possible to control the size and shape of the resulting nanoparticles (Vayssie'res et al. 1998, Khan et al. 2011, Mascolo et al. 2013). It was proved that particle sizes decrease with increasing $\mathrm{pH}$ and decreasing temperature of reaction (Mascolo et al. 2013, Petcharoen et al., 2012).

The objective of this work was to synthesize the magnetic iron oxide (magnetite) nanoparticles in different conditions by the co-precipitation method. After synthesis and post synthesis treatment nanoparticles were examined as heavy metal ions adsorbent. The main aim was to investigate how the co-precipitation synthesis conditions of magnetite influence its heavy metal ions separation ability. In the experiments, seven heavy metals were taken into consideration, i.e. $\mathrm{Cr}(\mathrm{VI}), \mathrm{Pb}(\mathrm{II})$, $\mathrm{Cr}(\mathrm{III}), \mathrm{Cu}(\mathrm{II}), \mathrm{Zn}(\mathrm{II}), \mathrm{Ni}(\mathrm{II})$ and $\mathrm{Cd}(\mathrm{II})$.

\section{Experimental}

\section{Chemicals}

The following chemicals were used for magnetite nanoparticles synthesis: $\mathrm{FeCl}_{3} \cdot 6 \mathrm{H}_{2} \mathrm{O}$ (Warchem, Poland), $\mathrm{FeSO}_{4} \cdot 7 \mathrm{H}_{2} \mathrm{O}$ and $\mathrm{NH}_{3} \cdot \mathrm{H}_{2} \mathrm{O} 25 \%$ solution (Stanlab, Poland). Heavy metal solutions were prepared using their salts, i.e. $\mathrm{Cr}\left(\mathrm{NO}_{3}\right)_{3} \cdot 9 \mathrm{H}_{2} \mathrm{O}$, $\mathrm{Ni}\left(\mathrm{NO}_{3}\right)_{2} \cdot 6 \mathrm{H}_{2} \mathrm{O}, \mathrm{Cd}\left(\mathrm{NO}_{3}\right)_{2} \cdot 4 \mathrm{H}_{2} \mathrm{O}, \mathrm{Cu}\left(\mathrm{NO}_{3}\right)_{2} \cdot 3 \mathrm{H}_{2} \mathrm{O}, \mathrm{Pb}\left(\mathrm{NO}_{3}\right)_{2}$, $\mathrm{Zn}\left(\mathrm{NO}_{3}\right)_{2} \cdot 9 \mathrm{H}_{2} \mathrm{O}$ (POCH S.A., Gliwice, Poland), $\mathrm{K}_{2} \mathrm{Cr}_{2} \mathrm{O}_{7}$ (Merck, Germany).

\section{Nanoparticles preparation and characterization}

The method used for magnetite synthesis was based on their co-precipitation from a mixture of $\mathrm{Fe}$ (II) and $\mathrm{Fe}$ (III) salt solutions with the addition of $25 \%$ ammonia solution to complete the following reaction:

$$
\mathrm{Fe}^{2+}+2 \mathrm{Fe}^{3+}+8 \mathrm{NH}_{3} \cdot \mathrm{H}_{2} \mathrm{O} \rightarrow \mathrm{Fe}_{3} \mathrm{O}_{4} \downarrow+8 \mathrm{NH}^{4+}+4 \mathrm{H}_{2} \mathrm{O}
$$

The synthesis reaction was conducted in different temperature/ammonia quantity conditions. The base volume was the factor which affected the $\mathrm{pH}$ of the reaction mixture. Moreover, the reaction was conducted under aerobic conditions so the partial oxidation of $\mathrm{Fe}$ (II) to $\mathrm{Fe}(\mathrm{III})$ was predicted. Because stoichiometric value of $\mathrm{Fe}(\mathrm{II})$ : $\mathrm{Fe}(\mathrm{III})$ molar ratio in magnetite equals $1: 2$, to compensate the process of oxidation during the synthesis reaction, the initial ratio of $\mathrm{Fe}(\mathrm{II}): \mathrm{Fe}(\mathrm{III})$ in the reaction solution was decreased to $1: 1.5$.

The amounts of iron salts used during the synthesis were prepared following Liu et al. method (Liu 2008) - $6.1 \mathrm{~g}$ $\mathrm{FeCl}_{3} \cdot 6 \mathrm{H}_{2} \mathrm{O}$ and $4.2 \mathrm{~g} \mathrm{FeSO}_{4} \cdot 7 \mathrm{H}_{2} \mathrm{O}$ were dissolved in $100 \mathrm{~cm}^{3}$ of distilled water. The mixture was placed in water bath and heated to reach a required temperature. Then, starting the mechanical stirring of the mixture, the appropriate volume of base in the form of $25 \%$ ammonia water was added to initiate magnetite precipitation. The magnetite syntheses were conducted at three temperatures $-30^{\circ} \mathrm{C}, 60^{\circ} \mathrm{C}$ and $90^{\circ} \mathrm{C}$ and for each temperature, three volumes of ammonia solution were added $-8 \mathrm{~cm}^{3}, 10 \mathrm{~cm}^{3}$ and $15 \mathrm{~cm}^{3}$ (thus nine synthesis reactions were carried out). The quantities of the reagents in comparison to the stoichiometric reaction are presented in Table 1.

After base addition, the stirring was continued for 30 minutes whilst keeping the mixture at stable temperature conditions. Afterwards, the mixture was cooled to room temperature, its $\mathrm{pH}$ was measured and the black precipitate of magnetite nanoparticles was washed approximately six times with $50 \mathrm{~cm}^{3}$ of distilled water with help of a neodymium magnet, in order to remove the unreacted residues of the chemicals. The final $\mathrm{pH}$ of the mixtures after iron oxides precipitation as well as the temperature and ammonia volumes conditions of each synthesis are given in Table 2 .

Then, following the synthesis treatment described by Schwertmann et al. (2000), the magnetite sample was dried in an oven at $40^{\circ} \mathrm{C}$ and crushed in an agate mortar to break up aggregates and to obtain the powder.

The sample synthesized at $30^{\circ} \mathrm{C}$ with $10 \mathrm{ml}$ of ammonia was used for further characterization. Qualitative and quantitative analysis of the sample as well as its particle size analysis were carried out by X-ray powder diffraction (XRD) in a Bruker Advance D8 powder diffractometer (Bruker, USA). The morphology and structure of the sample were investigated 
Table 1. Amounts of chemicals used in synthesis reactions

\begin{tabular}{|c|c|c|c|c|c|c|}
\hline $\mathrm{Fe}^{2+}$ & $\mathrm{Fe}^{3+}$ & \multicolumn{2}{|c|}{$\mathrm{NH}_{3} \cdot \mathrm{H}_{2} \mathrm{O}$} & $\mathrm{Fe}^{2+}$ & $\mathrm{Fe}^{3+}$ & $\mathrm{NH}_{3} \mathrm{H}_{2} \mathrm{O}$ \\
\hline $\mathrm{mol}$ & $\mathrm{mol}$ & $\mathrm{cm}^{3}$ & $\mathrm{~mol}$ & \multicolumn{3}{|c|}{ molar ratios of chemicals } \\
\hline & & & & 1 & 2 & $8^{*}$ \\
0.015 & 0.023 & 8.0 & 0.057 & 1.0 & 1.5 & 3.8 \\
0.015 & 0.023 & 10.0 & 0.071 & 1.0 & 1.5 & 4.7 \\
0.015 & 0.023 & 15.0 & 0.107 & 1.0 & 1.5 & 7.1 \\
\hline
\end{tabular}

*stoichiometric amounts of chemicals

Table 2. Experimental data

\begin{tabular}{|c|c|c|c|}
\hline $\begin{array}{c}\text { Number } \\
\text { of syntheses/combinations }\end{array}$ & Temperature & $\begin{array}{c}\text { Ammonia } \\
\text { water volume }\end{array}$ & $\begin{array}{c}\text { Final pH after } \\
\text { synthesis }\end{array}$ \\
\hline & ${ }^{\circ} \mathrm{C}$ & \multirow{2}{*}{$\mathrm{cm}^{3}$} & \\
\hline 1 & 30 & \multirow{2}{*}{8} & 7.31 \\
\hline 2 & 60 & & 5.81 \\
\hline 3 & 90 & & 5.31 \\
\hline 4 & 30 & \multirow{2}{*}{10} & 8.84 \\
\hline 5 & 60 & & 8.53 \\
\hline 6 & 90 & & 6.95 \\
\hline 7 & 30 & \multirow{2}{*}{15} & 9.37 \\
\hline 8 & 60 & & 9.16 \\
\hline 9 & 90 & & 7.92 \\
\hline
\end{tabular}

with Scanning Electron Microscope FEI Quanta 650 FEG (FEI, USA). Specific surface area and pore distribution of the sample were evaluated by Brunauer-Emmett-Teller (BET) and Barrett-Joyner-Halenda (BJH) method using TriStar II 3020 (V1.03) surface area and porosity measurement system (Micromeritics Inc., USA).

\section{Adsorption procedure}

Batch adsorption studies were conducted in order to examine the differences in heavy metal separation from the solution by magnetite nanoparticles synthesized in different temperature/ammonia quantity conditions. For each of the seven heavy metals, the adsorption process was conducted on each of the nine sorbents with three repetitions.

In every removal procedure, $50 \pm 1 \mathrm{mg}$ of previously prepared (at one of the nine synthesis reactions) dry magnetite powder was placed in a small plastic container and poured over with $20 \mathrm{~cm}^{3}$ of one metal solution at $10 \mathrm{mg} \cdot \mathrm{dm}^{-3}$ concentration. During the sorption process $\mathrm{pH}$ was not corrected and maintained as it settled itself. The $\mathrm{pH}$ values were measured immediately after pouring metal solution to the container and after sorption process at the adsorption equilibrium. So prepared adsorption reactor was placed on a mechanic shaker and shaken for 8 hours at room temperature. After that, the reactor was put on the neodymium magnet in order to help adsorbent sedimentation and $10 \mathrm{~cm}^{3}$ of supernatant was collected.

Atomic absorption spectrometer SepctrAA 880 (Varian) with atomization in the acetylene-air flame was used to determine the content of metal in the solution after the sorption process.

\section{Results and discussion}

\section{Sorption results}

Based on the concentration of heavy metal ion in the solution before and after sorption, the process efficiency $\eta$ was evaluated according to the following equation:

$$
\eta=\frac{C_{i}-C_{f}}{C_{i}} \cdot 100 \%
$$

where $C_{i}$ and $C_{f}$ are metal ion concentrations before and after sorption (initial and final concentration) respectively. At Figures 1-7 the separation efficiencies for each metal using iron oxides synthesised at different combinations of temperatures and base volumes, as well as $\mathrm{pH}$ values, are presented. At every diagram, for each combination only one $\mathrm{pH}$ value is shown because it turned out that it has remained almost unchanged during the sorption process.

While analysing the results, $\mathrm{pH}$ during the adsorption process is the first issue that should be taken into consideration as it is one of the main factors which influence process efficiency. Because the aim of this study was to compare adsorbents, which were precipitated in different conditions, it was important to maintain the stable $\mathrm{pH}$ in the reaction containers within each metal ion, during the sorption process. As it arises from the diagrams (Fig. 1-7) the $\mathrm{pH}$ values showed only slight fluctuations. For most of the ions they stayed in the range of 4-5 and do not exceed the $\mathrm{pH}$ of point of zero charge of magnetite. Moreover, the $\mathrm{pH}$ values were also low enough to avoid the metal hydroxides precipitation. Taking into account 
the above, it was assumed that during the sorption process the $\mathrm{pH}$ conditions were stable within each individual ion, so the data of sorption abilities of nine considered materials could be compared.

Comparing charts data of separation efficiencies, it is noticeable that the least differences in sorption on iron oxides synthesized under different conditions and, at the same time, the highest values of the metal ion removal were obtained for $\mathrm{Cr}(\mathrm{VI})$. Its separation using all adsorbents was above $90 \%$, reaching almost $100 \%$. For this metal it is hard to indicate which adsorbent and hence which synthesis conditions are more favourable.

High levels of separation were also reached for $\mathrm{Pb}(\mathrm{II})$ and $\mathrm{Cr}$ (III) ions. Their removal efficiencies varied from 76 to $92 \%$ and from 66 to $77 \%$ respectively. Moreover, it is visible that for $\mathrm{Pb}$ (II) ions material synthesised at $30^{\circ} \mathrm{C}$ with $10 \mathrm{~cm}^{3}$ of ammonia is more effective than the others. The usage of this adsorbent brought slight separation increase from a few to several percent when comparing it with the adsorption on the magnetite synthesised in other conditions. In turn, the adsorbent produced also at $30^{\circ} \mathrm{C}$ but with $15 \mathrm{~cm}^{3}$ of ammonia solution seems to be more favourable for $\mathrm{Cr}$ (III) ions removal.

The separation effectiveness for the rest of ions, i.e., $\mathrm{Cu}(\mathrm{II})$, $\mathrm{Zn}(\mathrm{II}), \mathrm{Ni}(\mathrm{II})$ and $\mathrm{Cd}(\mathrm{II})$, is evidently smaller. But on the other hand, for this group of metals, the adsorbent co-precipitated at $30^{\circ} \mathrm{C}$ and $10 \mathrm{~cm}^{3}$ of ammonia can be marked out, as the one whose separation ability is higher than that of the others. The sorption on this material led to $26 \%$ separation of $\mathrm{Cu}$ (II) and
$\mathrm{Zn}(\mathrm{II}), 21 \%$ of $\mathrm{Cd}(\mathrm{II})$ and $14 \%$ of $\mathrm{Ni}(\mathrm{II})$, while the removal of those ions using the other tested adsorbents reaches form 0 to only few percent.

Summing up, it can be said that lower temperatures are more suitable to synthesize the efficient magnetite adsorbent. The materials produced at $30^{\circ} \mathrm{C}$ were generally more effective than the others. It can be explained by the fact that the temperature may cause the particle growth acceleration what was proved in the literature (Petcharoen et al. 2012). Moreover, the lower the particles size, the bigger surface area of the material (Mascolo et al. 2013), what, in turn, improves its heavy metals adsorption ability.

It is suspected that the mechanism of the reactions which occurred during sorption experiments was the electrostatic attraction described in introduction. It is worth to mentioned that for most of the ions (cations) the process was led in not the most favourable $\mathrm{pH}$ levels $-\mathrm{pH}$ of the solutions was below point of zero charge (pzc) of magnetite It means that the adsorbents were more suitable to attract anions - predominant groups on their surface were $\mathrm{Fe}-\mathrm{OH}_{2}^{+}$. This is the reason why the highest removal efficiencies were achieved for $\mathrm{Cr}(\mathrm{VI})$ anions.

On the other hand, it can be said that $\mathrm{pH}$ in reaction containers for the rest of ions was not significantly far from pzc. Because of this fact the materials also demonstrated bigger or smaller affinity for cations $-\mathrm{Fe}-\mathrm{OH}^{-}$groups were still present. It is especially noticeable for $\mathrm{Pb}(\mathrm{II})$ and $\mathrm{Cr}(\mathrm{III})$ ions whose separations are high.

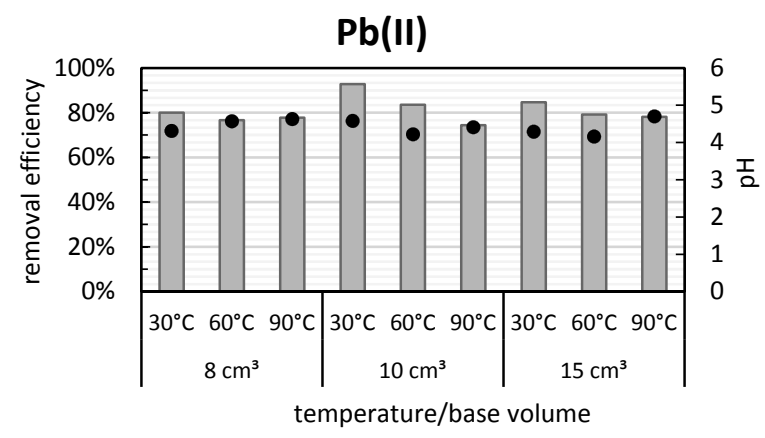

Fig. 2. Removal efficiency of $\mathrm{Pb}(\mathrm{II})$ ions by iron oxides synthesised at different ammonia volume/temperature conditions

Fig. 1. Removal efficiency of $\mathrm{Cr}(\mathrm{VI})$ ions by iron oxides synthesised at different ammonia volume/temperature conditions

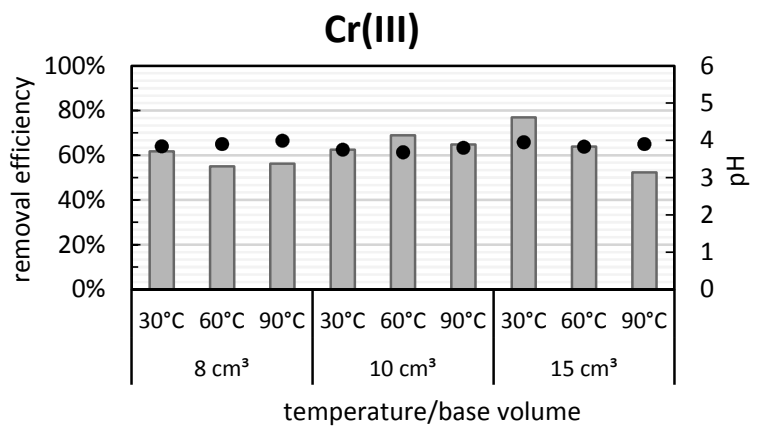

Fig. 3. Removal efficiency of $\mathrm{Cr}(\mathrm{III})$ ions by iron oxides synthesised at different ammonia volume/temperature conditions

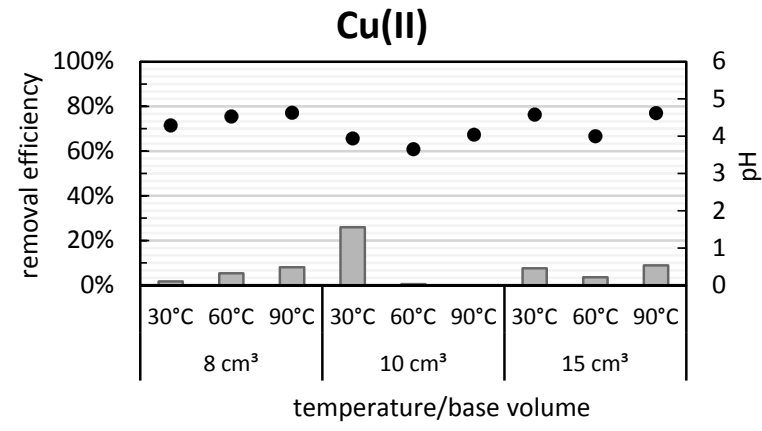

Fig. 4. Removal efficiency of $\mathrm{Cu}(\mathrm{II})$ ions by iron oxides synthesised at different ammonia volume/temperature conditions 


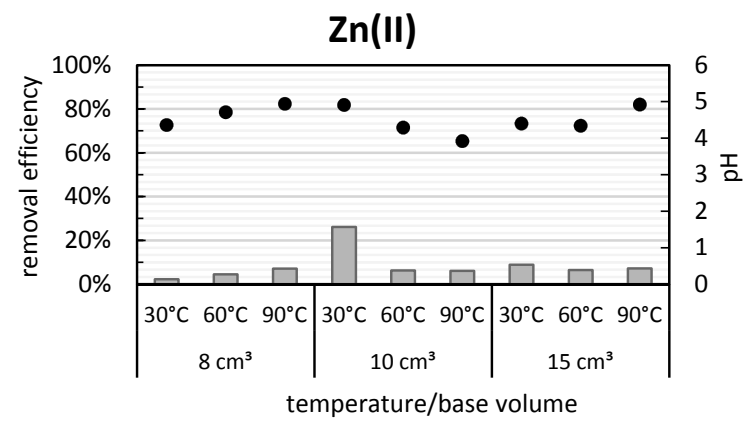

Fig. 5. Removal efficiency if $\mathrm{Zn}(\mathrm{II})$ ions by iron oxides synthesised at different ammonia volume/temperature conditions

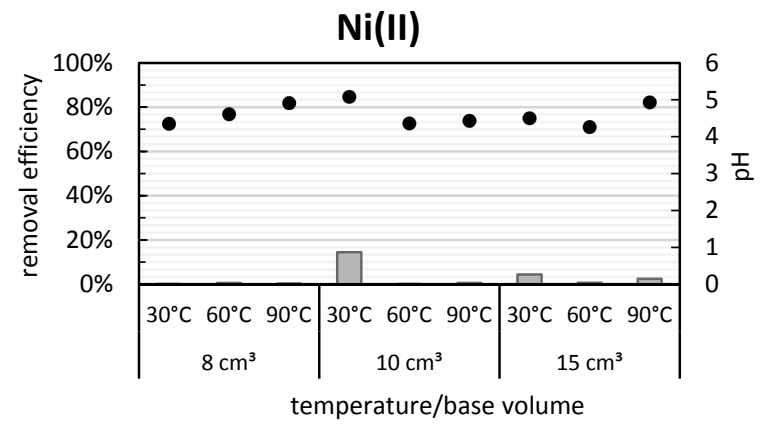

Fig. 6. Removal efficiency of $\mathrm{Ni}(\mathrm{II})$ ions by iron oxides synthesised at different ammonia volume/temperature conditions

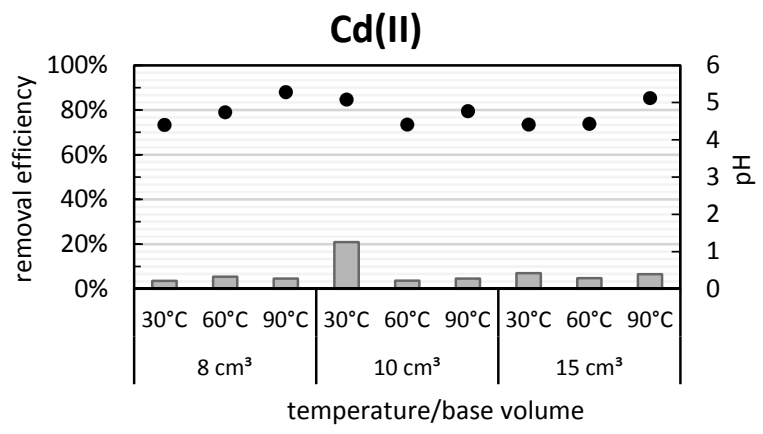

Fig. 7. Removal efficiency of $\mathrm{Cd}(\mathrm{II})$ ions by iron oxides synthesised at different ammonia volume/temperature conditions

\section{Sample characterization}

Characterization was made for the iron oxide sample synthesised at $30^{\circ} \mathrm{C}$ with $10 \mathrm{~cm}^{3}$ of ammonia addition which, for most of the examined heavy metal ions, had the best sorption ability. In Figure 8, the XRD pattern of the sample is shown. The obtained diffraction peaks fit well the standard XRD magnetite pattern from JCPDS - ICDD data base. Quantitative Rietveld analysis indicated magnetite to be the main $100 \%$ crystalline compound in the sample. The crystallite size was estimated at $23.2 \mathrm{~nm}$ from the most intense reflection according to the Scherrer's formula.

Figure 9 shows SEM images. The irregular, micrometric (from a few to several hundred micrometers in size) aggregates of the magnetite sample crushed in a mortar are visible. Each of them is the agglomeration of nanosized iron oxides. This form of the sample is due to its after-synthesis treatment procedure. Drying of iron oxides in the form of wet precipitate causes their agglomeration, thus magnetite powder has a form of aggregated agglomerates in micrometric sizes.

Based on argon adsorption/desorption isotherms determined by BET method, the specific surface area of the sample was determined to be $55.64 \mathrm{~g} \cdot \mathrm{m}^{-2}$. BJH desorption pore size and volume analysis are presented in Figure 10. Two prevailing pore sizes were distinguished -6.81 and $2.55 \mathrm{~nm}$. The pore size is affected by the size of individual particle of magnetite. In the case of research material the pore sizes indicates that the material is mesoporous (according to IUPAC classification).

The agglomeration of the iron oxides nanoparticles, even when they are left in the suspension form (without drying), is

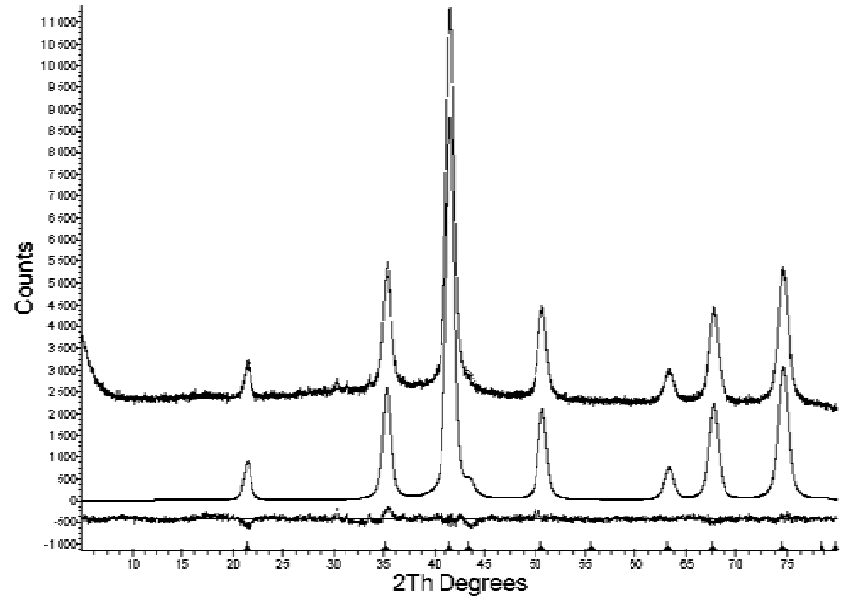

Fig. 8. X-ray diffraction pattern of magnetite synthesised at $30^{\circ} \mathrm{C}$ with $10 \mathrm{ml}$ ammonium hydroxid

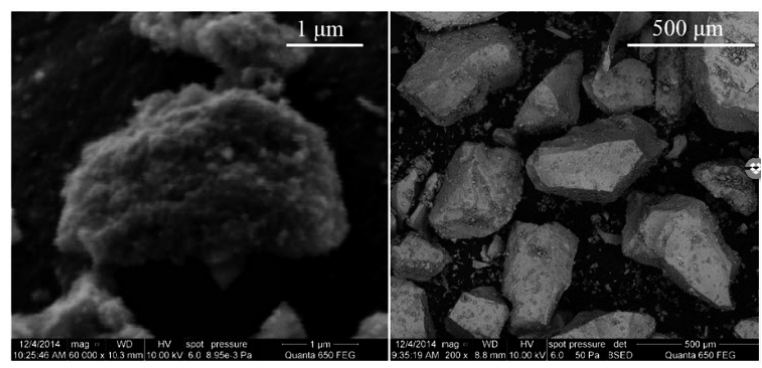

Fig. 9. SEM images of mortar crushed magnetite agglomerates used in heavy metal separation process 


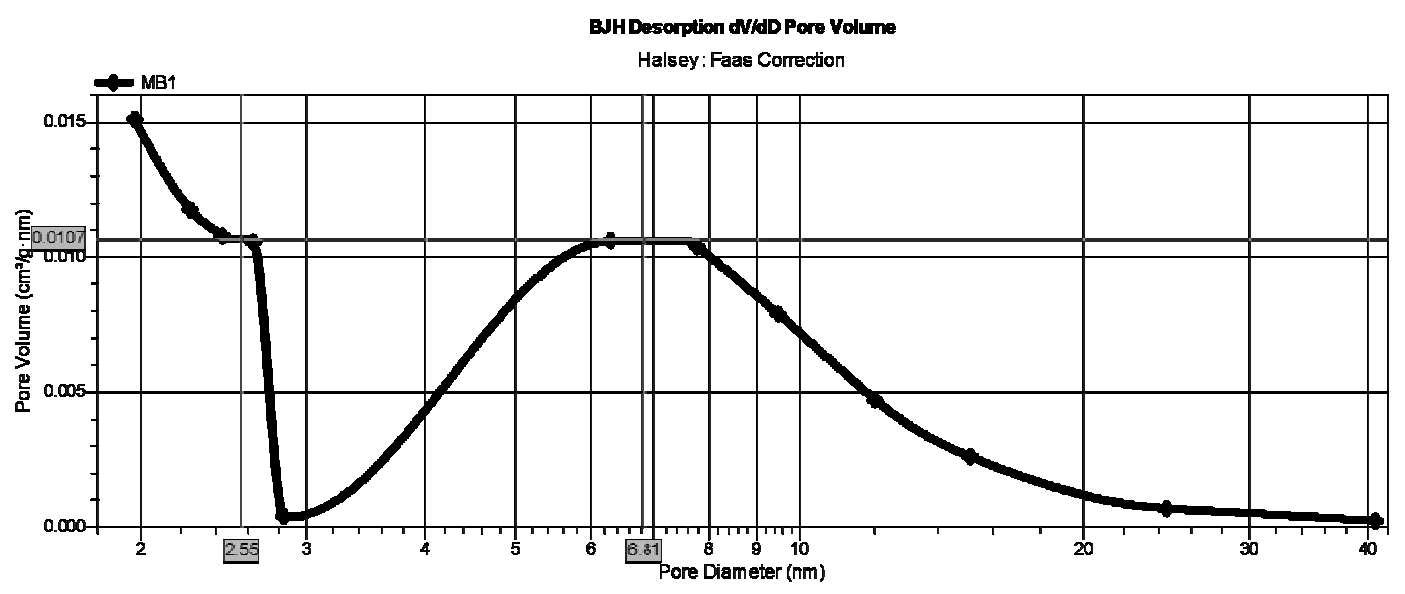

Fig. 10. BJH desorption pore size distribution curve

widely reported in the literature. This phenomenon is especially common when the nanoparticles are synthesised without surfactant addition. It is worth to mention that although the researched material aggregates were large in size, their surface area was comparable to the results obtained in other studies. In the work of Liu et. al. the aggregates of $10 \mathrm{~nm}$ nanoparticles in average size of $120 \mathrm{~nm}$ give surface area equal to $62 \mathrm{~g} \cdot \mathrm{m}^{-2}$ (Liu et al. 2008). In turn, Mascolo et al. proved that the nanoparticles in average sizes of $11.5 \mathrm{~nm}$ agglomerate giving the mesoporous material with the surface area of about $90 \mathrm{~g} \cdot \mathrm{m}^{-2}$ (Mascolo et al. 2013).

\section{Conclusions}

The first thing which is noticeable in the adsorption tests results is the general tendency of heavy metal ions removal. Although all tested magnetites were precipitated separately, each of them gave very good results in $\mathrm{Cr}(\mathrm{VI}), \mathrm{Pb}$ (II) separation, slightly worse in $\mathrm{Cr}$ (III) removal and much worse in separation of the rest metal ions considered, i.e. $\mathrm{Cu}$ (II), Ni(II), $\mathrm{Zn}$ (II) and $\mathrm{Cd}$ (II)

Moreover, it was proved that co-precipitation conditions of adsorbent in some cases influence its separation ability. The material synthesized in the reaction at $30^{\circ} \mathrm{C}$ and with $10 \mathrm{~cm}^{3}$ of ammonia was more suitable for removal of $\mathrm{Pb}(\mathrm{II}), \mathrm{Zn}(\mathrm{II})$, $\mathrm{Ni}(\mathrm{II}), \mathrm{Cd}(\mathrm{II})$ and $\mathrm{Cu}(\mathrm{II})$ ions than other materials.

It should be also mentioned that the sorption processes were led without $\mathrm{pH}$ correction so it is highly probable that retention of some metal ions was not as high as it would be possible in more favourable $\mathrm{pH}$ conditions. The sorptions of all the ions were conducted below point of zero charge of the adsorbent, when its surface is in general positively charged and more likely attracts anions. That is why the best separation effectiveness was obtained for $\mathrm{Cr}(\mathrm{VI})$ ions. Nonetheless, due to the presence of some negatively charged sites on adsorbent at $\mathrm{pH}$ below pzc, bigger or smaller affinity for the rest of the ions (cations) was also noticeable. To conclude, in the work heavy metal ions were retained in the following order: $\mathrm{Cr}(\mathrm{VI})$ $>\mathrm{Pb}(\mathrm{II})>\mathrm{Cr}(\mathrm{III})>\mathrm{Zn}(\mathrm{II})>\mathrm{Cu}(\mathrm{II})=\mathrm{Cd}(\mathrm{II})>\mathrm{Ni}(\mathrm{II})$

Representative magnetite sample synthesized at $30^{\circ} \mathrm{C}$ and with $10 \mathrm{~cm}^{3}$ of ammonia was subjected to a further testing. XRD pattern proved that the iron oxides produced in these conditions formed pure, crystalline magnetite with the grain size of about $23 \mathrm{~nm}$. Because of the post-synthesis treatment of the sample
- drying and crushing in the mortar, nanoparticles underwent strong aggregation. It was especially noticeable in the SEM images - the magnetite powder used in the sorption process consists of micrometric agglomerates of magnetite nanoparticles, which, according to BHJ and BET testing, constitute mesoporous material with a specific surface area of $56 \mathrm{~g} \cdot \mathrm{m}^{-2}$.

\section{Acknowledgement}

This work was supported by the Silesian University of Technology project no BKM-539/RIE4/2015.

\section{References}

Dave, P.N. \& Chopda, L.V.(2014). Application of iron oxide nanomaterials for the removal of heavy metals, Journal of Nanotechnology, vol. 2014, ID 398569, 14 pages, doi:10.1155/2014/398569

Dąbkowska-Naskręt, H. (2009). Natural and synthetic iron oxides as adsorbents of trace elements in soils, Environmental Protection and Natural Resources, 41, pp. 631-639.

Horst, M.F., Lassalle, V. \& Ferreira, M.L. (2015). Nanosized magnetite in low cost materials for remediation of water polluted with toxic metals, azo- and antraquinonic dyes, Frontiers of Environmental Science and Engineering, 9(5), pp. 746-769.

Hu, D., Wang, Y. \& Song, Q. (2010). Weakly magnetic field-assisted synthesis of magnetite nano-particles in oxidative co-precipitation, Particuology, 7(5), pp. 363-367.

Illés, E. \& Tombácz, E. (2006), The effect of humic acid adsorption on $\mathrm{pH}$-dependent surface charging and aggregation of magnetite nanoparticles, Journal of Colloid and Interface Science, 295, pp. $115-123$.

Khan, U.S., Khattak, N.S., Rahman, A. \& Khan, F. (2011). Historical development of magnetite nanoparticles synthesis, Journal of The Chemical Society Of Pakistan, 33(6), pp. 793-804.

Liu, J.F., Zhao, S.Z. \& Jiang, G.B. (2008). Coating $\mathrm{Fe}_{3} \mathrm{O}_{4}$ Magnetite nanoparticles with humic acid for high efficient removal of heavy metals in water, Environmental Science \& Technology, 42, pp. 6949-6954.

Maity, D. \& Agrawal, D. (2006), Synthesis of iron oxide nanoparticles under oxidizing environment and their stabilization in aqueous and non-aqueous media, Journal of Magnetism and Magnetic Materials, 308, pp. 46-55.

Mascolo, M., Pei, Y. \& Ring, T. (2013), Room temperature co-precipitatio synthesis of magnetite nanoparticles in large $\mathrm{pH}$ window with different bases, Materials, 6, pp. 5549-5567. 
Matei, E., Predescu, A. \& Vasile, E. (2011). Properties of magnetite iron oxides used as materials for wastewater treatment, Journal of Physics: Conference Series 304.

Petcharoen, K. \& Sirivat, A. (2012). Synthesis and characterization of magnetite nanoparticles via the chemical co-precipitation method, Materials Science and Engineering: B, 177(5), pp. 421-427.

Qu, S., Yang, H., Ren, D., Kan, S., Zou, G., Li, D. \& Li, M. (1999). Magnetite nanoparticles prepared by precipitation from partially reduced ferric chloride aqueous solutions, Journal of Colloid and Interface Science, 215(1), pp. 190-192.

Runowski, M. (2014). Nanotechnology-nanomaterials, nanoparticles and multifunctional core/shell type nanostructures, Chemik, 68(9), pp. 766-775

Salado, J., Insausti, M., Gil de Muro, I., Lezama, L. \& Rojo, T. (2008). Synthesis and magnetic properties of monodisperse $\mathrm{Fe}_{3} \mathrm{O}_{4}$ nanoparticles with controlled sizes, Journal of Non-Crystalline Solids, 354, pp. 5207-5209.

Schwertmann, U. \& Cornell, R.M. (2000). Iron Oxides in the Laboratory: Preparation and Characterization, ISBN: 783527613229.

Teja, A.S. \& Koh, P.-Y. (2009). Synthesis, properties, and applications of magnetic iron oxide nanoparticles, Progress in Crystal Growth and Characterization of Materials, 55, pp. 25-45.

Urquijo, J.P. \& Casanova, H. (2011). Synthesis of magnetite nanoparticles: effects of polyelectrolyte concentration and $\mathrm{pH}$, Hyperfine Interactions, 203(1-3), pp. 85-91.

Vayssie`res, L., Chane'ac, C., Tronc, E. \& Jolivet, J.P. (1998). Size tailoring of magnetite particles formed by aqueous precipitation: an example of thermodynamic stability of nanometric oxide particles, Journal of Colloid and Interface Science, 205, pp. 205-212.

\section{Wpływ warunków syntezy nanocząstek magnetytu na ich zdolność do separacji jonów metali cięż̇ich}

Streszczenie: Nanocząstki magnetytu stanowią obiecujący materiał badań ze względu na możliwość ich praktycznego zastosowania w różnorodnych dziedzinach. Wśród wielu metod ich syntezy, jako jedną z najwygodniejszych, najmniej pracochłonnych oraz ekonomicznych, wyróżnić można chemiczne współstrącanie. Efektem metody chemicznego współstrącania są drobne nanocząstki tlenku żelaza o dużej czystości, odpowiednie do zastosowań w zagadnieniach środowiskowych. Celem pracy było badanie w jaki sposób warunki syntezy chemicznego współstrącania, takie jak temperatura reakcji czy też ilość użytej zasady wpływają na zdolności separacyjne nanocząstek magnetytu względem jonów kilku metali ciężkich. Syntezy prowadzone były w dziewięciu kombinacjach przy różnej objętości dodawanego amoniaku $-8 \mathrm{~cm}^{3}, 10 \mathrm{~cm}^{3}, 15 \mathrm{~cm}^{3}$ oraz temperaturze $-30^{\circ} \mathrm{C}$, $60^{\circ} \mathrm{C}, 90^{\circ} \mathrm{C}$. Powstałe podczas każdej z syntez tlenki żelaza były badane jako adsorbenty jonów siedmiu metali ciężkich: $\mathrm{Cr}(\mathrm{VI}), \mathrm{Pb}(\mathrm{II}), \mathrm{Cr}(\mathrm{III}), \mathrm{Cu}(\mathrm{II}), \mathrm{Zn}(\mathrm{II}), \mathrm{Ni}(\mathrm{II})$ and $\mathrm{Cd}(\mathrm{II})$. Ponadto próbka magnetytu zsyntezowanego w wybranych warunkach była badana przy użyciu metod XRD,

SEM oraz BET. Analizując wyniki procesu sorpcji stwierdzono, iż najbardziej efektywny materiał, dla większości metali ciężkich, powstał w temperaturze $30^{\circ} \mathrm{C}$ przy użyciu $10 \mathrm{~cm}^{3}$ amoniaku. Dodatkowa charakterystyka powstałego w tych warunkach sorbentu wykazała, iż stanowił on czysty magnetyt o średniej wielkości ziarna 23,2 nm (XRD). Ponadto wykazano, iż pojedyncze ziarna w badanej próbce są zaglomerowane (SEM) a powierzchnia właściwa agregatów wynosi 55,64 m²/g (BET). Ogólnym wnioskiem z pracy jest dowód, iż warunki syntezy badanego adsorbentu mają wpływ na jego zdolność separacyjne względem niektórych jonów metali ciężkich. 